\begin{tabular}{|c|c|c|}
\hline 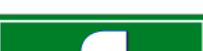 & Int.J.Curr.Microbiol.App.Sci (2021) 10(08): 510-522 & $=$ \\
\hline & $\begin{array}{l}\text { International Journal of Current Microbiology and Applied Sciences } \\
\text { ISSN: 2319-7706 Volume } 10 \text { Number } 08 \text { (2021) } \\
\text { Journal homepage: } \underline{\text { http://www.ijcmas.com }}\end{array}$ & 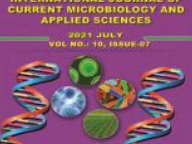 \\
\hline $\begin{array}{l}\text { EXCELLENT } \\
\text { PUBLISHERS }\end{array}$ & & \\
\hline
\end{tabular}

\title{
Microbial Analysis and Quality Assurance of Unpasteurized Raw and Pasteurized Branded Milk
}

\author{
Prerna Sinha $^{1}$, Sumedha Srivastava ${ }^{1}$, Sefali Gupta ${ }^{1}$ and O. P. Verma ${ }^{2 *}$ \\ ${ }^{1}$ Department of Industrial Microbiology, ${ }^{2}$ Department of molecular and Cellular Engineering, \\ Jacob Institute of Biotechnology and Bioengineering, Sam Higginbottom University of \\ Agriculture Technology and Sciences, Prayagraj-211007, U.P., India \\ *Corresponding author
}

Keywords

Milk,

contamination, content, quality, standards

Article Info

Accepted:

20 July 2021

Available Online:

10 August 2021

\section{A B S T R A C T}

Milk is a complete diet containing all essential nutritional constituents which have special significance in terms of properties such as protein, fat, mineral, vitamins and other ingredients dispersed in water. According to FDA (Food and Drug Administration), milk is recommended to be kept under refrigeration at or below $4{ }^{\circ} \mathrm{C}$ to increase its shelf life period. Processes like pasteurization eliminates pathogenic microorganisms and also has significant effects on physical and chemical properties of milk. Microbial contamination might generally occur within the udder and exterior to the udder and also from the storage equipment used while milk handling. Some of the pathogenic bacteria that are generally isolated from milk are E.coli, Proteus vulgaris, Klebsiella, Pectobacterium, Citrobacter koseri, etc. Therefore the present study concedes to identify the total bacterial load along with the total content of protein, carbohydrate, fat, calcium etc. in unpasteurized open milk and pasteurized branded milk samples. The study was aimed to evaluate the extent of microbial contamination, physical and chemical properties of milk and its hygienic quality. Through the various physico-chemical and biochemical tests applied, it was ensured that the milk samples were of satisfactory quality and thus fit for human consumption.

\section{Introduction}

Milk is a complex mixture and one of the utmost reasonable foundations of much nutrition like proteins, vitamins, minerals and macronutrients. Humans have been preserving milk for centuries. Hence it is necessary to look after the microbial load and the quality assurance of milk to be safer and healthier. According to PFA-1954 (Prevention of Food Adulteration Act) definition of milk, "Milk is the normal mammary secretion derived from complete milking of healthy milch animal". It contains more than 100 substances that are 
either in solution, suspension or emulsion form in water, the most important being casein- the major protein of milk, lactosemilk sugar, whey and mineral salts. Milk supplies body building proteins, bone forming minerals and giving lactose besides supplying certain essential fatty acids. Milk is a highly nutritious food that serves as an excellent growth medium for a wide range of microorganisms.

The microbiological quality of milk and dairy products is influenced by the initial flora of raw milk, the processing conditions and post heat treatment contamination.(Rajagopal et al., 2005)

Undesirable microbes that can causes poilage of dairy products include gram negative psychrotrophs, lactic acid bacteria, coliforms. Some of the pathogenic strains of Escherichia coliand enterotoxigenic strains of Staphylococcus aureus may also spoil milk and dairy products (Oliver et al., 2009).

The quality of milk is resolute by facets of composition and hygiene. Due to its chemical composition and high water activity, milk aids as an outstanding culture medium for the growth and multiplication of numerous kinds of microorganisms.

The microbiological quality of milk is basically influenced by the initial flora of raw milk, the processing conditions, and post heat treatment contamination.

Consequently while milk processing, in order to make milk safer for consumption; methods such as pasteurization and homogenization are used.

Unprocessed milk harbours various microorganisms which may produce unwanted effects on taste and smell of dairy products. Some pathogenic microorganisms also yield food infections which impose significant risks on consumers 'health

\section{Materials and Methods}

\section{Place of work}

The present study entitled "Microbial analysis and quality assurance of unpasteurized raw and pasteurized branded milk" was conducted in the Under Graduate Lab, Department of Industrial Microbiology, Jacob Institute of Biotechnology and Bioengineering, SHUATS, Prayagraj, U.P., India.

\section{Sample collection}

Two unpasteurized milk samples (cow and buffalo milk) were collected from local vendors and four pasteurized branded milk samples (Brand A, Brand B, Brand C and Brand D) from street shops in the city of Prayagraj, U.P.

\section{Primary analysis of milk}

Milk samples collected were subjected to various microbial and biochemical tests.

\section{Physical tests}

Any spoilage in the processed food is firstly detected by its change in physical appearance. So, the Food Product Order (FPO) and Bureau of Indian Standards (BIS) has assigned different parameters to be analyzed in different processed food. Some of the physical parameters which were analyzed in the quality control of the milk processed food products are color, taste and flavor.

\section{Chemical tests}

\section{pH}

Growth and the survival of microorganisms are greatly influenced by the $\mathrm{pH}$ of the 
environment. Thus it acts as one of the important chemical parameter in the analysis of food products. The pHs of all the milk samples were tested using a $\mathrm{pH}$ paper.

\section{Acidity test}

Acidity of food is due to the production of acid like lactic acid, acetic acid, tartaric acid, formicacid, etc during food processing. According to FPO and BIS, acidity can be measured by titration of the sample food against alkali solution using phenolphthalein as indicator.

\section{Carbohydrates (\%)}

Benedict's test is used to determine the percentage of simple carbohydrates. This test identifies reducing sugars (monosaccharides and some disaccharides).

\section{Fat Test}

Fat test was conducted by Gerber's Method.

\section{Protein test}

The total protein in milk can be determined by formal titration method (Pyne's method).

Methylene blue reductase test (MBRT): (Cappuccino and Sherman, 2009)

\section{Alcohol Test}

The alcohol test is performed on milk to indicate whether it will coagulate on thermal processing.

\section{Alcohol-Alizarin Test}

Alizarin is a colour indicator that changes colour according to the acidity levels of the sample.

\section{Isolation of microorganisms}

For Total Bacterial Count, milk samples diluted upto $10^{-5}$ dilutions were spread plated on Nutrient agar medium.

The plates were in cubated at $37^{\circ} \mathrm{C}$ for $24 \mathrm{hrs}$. Thus, pure culture of microorganisms were obtained (Cappuccino and Sherman, 2009)

\section{Screening of microorganism}

The bacterial isolates were further streaked on Eosin Methylene Blue agar medium which is as elective and differential medium for coliforms.

The isolates were also streaked on Mac Conkey agar medium to selectively differentiate Gram-negative and enteric bacilli on the basis of their ability to ferment lactose. All the plates were incubated at $37^{\circ} \mathrm{C}$ for $24 \mathrm{hrs}$ (Cappuccino and Sherman, 2009)

\section{Identification and characterization of bacterial isolates}

The isolated microbes were identified based on their colony characteristics, morphological and biochemical tests which included Indole test, Methyl red test, Voges Proskauer test, Citrate test, Catalase test, Oxidase test, Triple sugar iron agar test, Urease test, Nitrate test and Gelatin hydrolysis test were performed (Cappuccino and Sherman, 2009)

\section{Morphological characterization}

\section{Gram Staining}

The gram staining method developed by Dr. Hans Christian Gram, in 1884 is used for identifying and classifying bacteria into two major groups (Cappuccino and Sherman, 2009) 


\section{Results and Discussion}

\section{Physico-chemical analysis of milk sample}

\section{Physical Tests}

The physical parameters of both unpasteurized and pasteurized milk samples were checked on the basis of organoleptic test (Saiqa et al., 2013) as shown in Table 1.

The color difference in milk was observed due to change in feeding habits of animal. The animal which eats more consolidated feed has more yellowish color of milk (Saiqa et al., 2013).The variations of taste in different milk samples also depends on feeding habits of animals (Saiqa et al., 2013).The taste of unpasteurized milk was found slightly sweet which is similar to the finding of Chanda et al.,(2007). Commonly, milk flavor is based on animals' feed; those animals that eat herbs or bushes have unpleasant smell that gives the off flavor, which is objectionable. Animals feeding on fresh pasture produce milk with more pleasant flavor (Habib Ahmed and Shahzad Akbar, 2013).

\section{Chemical Tests}

\section{pH Test}

The $\mathrm{pH}$ of different milk samples are shown in the Table 2. Both the unpasteurized milk samples (cow and buffalo) were found to be slightly acidic while the pasteurized branded samples were found almost neutral.

Both the unpasteurized milk samples were found to be slightly acidic while the pasteurized branded samples were found almost neutral. The first milk produced by a cow or a buffalo contains colostrum, which lowers its $\mathrm{pH}$ (Anne Marie Helmenstine, 2019). The normal $\mathrm{pH}$ of milk ranges from 6.5-6.7, while some sources cite milk due to processing so that mixing milk with other chemicals brings close to the neutral $\mathrm{pH}$ of 7.0(Anne Marie Helmenstine,2019).

\section{Acidity Test}

The total lactic acid content in different milk samples are shown in Table 3. (Zulfiqar et al., 2013) had demonstated that the acidity of unpasteurized milk was significantly higher than that of pasteurized milk. The reason behind this could be the storage of unpasteurized milk in unsterilized utensils which enhance milk acidity.

The normal acidity of milk ranges from 0.10 to $0.26 \%$ lactic acid (Wong et al., 1988). Milk having acidity more than this range indicates microbial proliferation due to which the lactose present in milk gets converted into lactic acid. As acidity of milk increases, its keeping quality and heat stability gets reduced. Thus, total lactic content appears to be a valid parameter of evaluating milk quality (Karen et al., 2006).

\section{Carbohydrate Test}

The total carbohydrate content in different milk samples is described in Table 5. The results obtained from Benedict's test are interpreted as per color change observed in each sample which accounts for a specific percentage of sugar present in the sample (Sagar Aryal,2018) (Table 4). The results indicated that unpasteurized milk samples were thicker and denser in calories with a high percentage of carbohydrates present in them as shown in Table 5. For those aspiring for healthy weight gain, unpasteurized milk can be the preferred option. (Ghada, 2005). On the contrary branded milk samples were found to be having lesser carbohydrates. Lactose is the main carbohydrate of milk (Guetouache et al., 2014). Normally, the amount of lactose ranges from 4.5 to $5.2 \mathrm{~g} / 100 \mathrm{~g}$ of milk (Konte, 1999). 
Contrary to physical parameters, the carbohydrate content cannot be easily modified by feeding habits of animals (Guetouache et al., 2014).

\section{Fat test}

The total lipid content in different milk samples are shown in Table 6. The results indicated that buffalo milk has the highest fat content among all the milk samples which is on average nearly twice as high as that of pasteurized branded milk samples. This acts as a major reason behind using buffalo milk with considerable success for cheese, butter and ghee making, especially in countries where buffalo milk predominates (Khedkar and Kalyankar, 2016). Emmanuel et al., (2018) conducted a study in which fat content (\%) (Gerber method) of 2 liquid raw milk samples was found to be $3.96 \pm 0.001$ and $4.04 \pm 0.02$ respectively. The results in the study demonstrated that higher values off at content was reported from milk of animals feeding on natural raw pasture without processing the milk further.

\section{Protein Test}

The total protein content of different milk samples are shown in Table 7. From the results obtained buffalo milk was found to be the richest in protein content as compared to other milk samples. Buffalo milk proteins are complete proteins of high quality, that is, they contain all the essential amino acids in proportions required by the body (Khedkar and Kalyankar, 2016).

Emmanuel et al., (2018) conducted a study in which the protein content (\%) of 2 unpasteurized buffalo milk samples were found to be $3.05 \pm 0.02$ and $3.55 \pm 0.01$ respectively. The results in the study demonstrated that fresh natural raw milk is a rich source of protein while in processed milk samples, some of the proteins might be lost due to the processing methods.

\section{MBRT}

The MBRT test results of different milk samples are described in Table 9. The results from the MBRT test are interpreted as per the BIS (Bureau of Indian Standards) criterion for grading of milk (Table 8). Results indicated that 2 out of $4(50 \%)$ pasteurized milk samples took more than $5 \mathrm{hrs}$ to reduce methylene blue which refers to their superior quality. Quality of unpasteurized milk samples was fine but not better than the pasteurized ones. Sudhasaravanan et al.,(2015) conducted a similar study in which 240 unpasteurized raw milk and 72 pasteurized branded milk samples were subjected to MBRT test. The results in this study revealed that out of 240 raw milk samples tested, $52(21.6 \%)$ samples were found to be good, 67 (27.9\%) samples were fair. However, the highest number of samples were found to be poor $71(29.5 \%)$ and very poor $72(30.0 \%)$. Out of 72 pasteurized milk samples, highest number of samples were found to be good $59(81.9 \%)$, only $3(4.1 \%)$ samples were found to be very poor and $4(5.5 \%)$ samples were poor. In the study it was reported that the raw milk contained higher number of microflora probably due to contamination from the animal.

\section{The Alcohol Test}

The presence/absence of clots in different milk samples after addition of alcohol has been shown in Table 10. Milk which passes alcohol test is considered as that of superior quality and is chosen for manufacturing Ultra-High Temperature (UHT) products (Adongo 2013). In this case, clots were observed for unpasteurized milk samples which indicates higher levels of albumen and salt concentrates. Kentaro Mitamura (2007) conducted a study to check alcohol susceptibility of raw milk. 
Table.1 Physical test of milk

\begin{tabular}{|c|c|c|c|c|c|c|}
\hline $\begin{array}{c}\text { Physic } \\
\text { al } \\
\text { Param } \\
\text { eter }\end{array}$ & $\begin{array}{c}\text { Unpasteurize } \\
\text { dCow }\end{array}$ & $\begin{array}{c}\text { Unpasteurized } \\
\text { Buffalo }\end{array}$ & $\begin{array}{c}\text { PasteurizedB } \\
\text { randA }\end{array}$ & $\begin{array}{c}\text { Pasteurized } \\
\text { Brand B }\end{array}$ & $\begin{array}{c}\text { Pasteurized } \\
\text { Brand C }\end{array}$ & $\begin{array}{c}\text { Pasteuri } \\
\text { zed } \\
\text { Brand } \\
\text { D }\end{array}$ \\
\hline Color & Pale yellow & Pale yellow & White & White & White & White \\
\hline Taste & $\begin{array}{c}\text { Little Sweet, } \\
\text { fresh }\end{array}$ & $\begin{array}{c}\text { Little Sweet, } \\
\text { fresh }\end{array}$ & Creamy & Creamy & Creamy & Creamy \\
\hline Flavor & $\begin{array}{c}\text { Acceptable } \\
\text { Acceptable }\end{array}$ & Acceptable & Acceptable & Acceptable & $\begin{array}{c}\text { Accepta } \\
\text { ble }\end{array}$ \\
\hline
\end{tabular}

Table. $2 \mathrm{pH}$ of milk samples

\begin{tabular}{|c|c|}
\hline Sample & $\begin{array}{c}\text { pH } \\
\text { (approximately) }\end{array}$ \\
\hline Unpasteurized Cow & $\mathbf{6}$ \\
\hline Unpasteurized Buffalo & $\mathbf{6}$ \\
\hline Pasteurized Brand A & $\mathbf{7}$ \\
\hline Pasteurized Brand B & $\mathbf{7}$ \\
\hline Pasteurized Brand C & $\mathbf{7}$ \\
\hline Pasteurized Brand D & $\mathbf{7}$ \\
\hline
\end{tabular}

Table.3 Total lactic acid content in different milk samples

\begin{tabular}{|c|c|}
\hline Sample & \% Lactic Acid \\
\hline Unpasteurized Cow & $\mathbf{0 . 1 5}$ \\
\hline Unpasteurized Buffalo & $\mathbf{0 . 1 7}$ \\
\hline Pasteurized Brand A & $\mathbf{0 . 1 0}$ \\
\hline Pasteurized Brand B & $\mathbf{0 . 1 2}$ \\
\hline Pasteurized Brand C & $\mathbf{0 . 1 1}$ \\
\hline Pasteurized Brand D & $\mathbf{0 . 1 4}$ \\
\hline
\end{tabular}

Table.4 Interpretation of results obtained from Benedict's Test

\begin{tabular}{|c|c|}
\hline Color Change & \% Sugar \\
\hline Yellow & $0.5-1$ \\
\hline Orange & $1-1.5$ \\
\hline Red & $1.5-2.0$ \\
\hline Brick red & More than 2 \\
\hline
\end{tabular}


Table.5 Total carbohydrate content in different milk samples

\begin{tabular}{|c|c|c|}
\hline Sample & Color Change & \%Sugar \\
\hline Unpasteurized Cow & Brick red & More than 2\% \\
\hline Unpasteurized Buffalo & Brick red & More than 2\% \\
\hline Pasteurized Brand A & Orange & $\mathbf{1 t o 1 . 5 \%}$ \\
\hline Pasteurized Brand B & Greenish yellow & $\mathbf{0 . 5 t o 1 \%}$ \\
\hline Pasteurized Brand C & Orange & $\mathbf{1 t o 1 . 5 \%}$ \\
\hline Pasteurized Brand D & Green & $\mathbf{0 . 1 t o 0 . 5 \%}$ \\
\hline
\end{tabular}

Table.6 Total Lipid content in different milk samples

\begin{tabular}{|c|c|}
\hline Sample & \% Lipid \\
\hline Unpasteurized Cow & $\mathbf{5 . 4 9 \%}$ \\
\hline Unpasteurized Buffalo & $\mathbf{7 . 4 8 \%}$ \\
\hline Pasteurized Brand A & $\mathbf{4 . 8 1 \%}$ \\
\hline Pasteurized Brand B & $\mathbf{4 . 9 6 \%}$ \\
\hline Pasteurized Brand C & $\mathbf{3 . 7 3 \%}$ \\
\hline Pasteurized Brand D & $\mathbf{3 . 1 2 \%}$ \\
\hline
\end{tabular}

Table.7 Total Protein content in different milk sample

\begin{tabular}{|c|c|}
\hline Sample & \% Protein \\
\hline Unpasteurized Cow & $3.25 \%$ \\
\hline Unpasteurized Buffalo & $3.57 \%$ \\
\hline Pasteurized Brand A & $\mathbf{2 . 5 5 \%}$ \\
\hline Pasteurized Brand B & $\mathbf{2 . 5 1 \%}$ \\
\hline Pasteurized Brand C & $\mathbf{2 . 3 4 \%}$ \\
\hline Pasteurized Brand D & $\mathbf{2 . 0 2 \%}$ \\
\hline
\end{tabular}

Table.8 Interpretation of MBRT test results as per the BIS criterion

\begin{tabular}{|c|c|}
\hline Reduction Time & Milk Quality \\
\hline 5hrs and above & Very Good \\
\hline 3 to 4 hrs ;P;P & Good \\
\hline 1 to 2 hrs & Fair \\
\hline 30 minutes or less & Poor \\
\hline
\end{tabular}


Table.9 MBRT test performed on different milk samples

\begin{tabular}{|c|c|c|}
\hline Sample & Reduction Time & Milk Quality \\
\hline Unpasteurized Cow & 3 to $4 \mathrm{hrs}$ & Good \\
\hline Unpasteurized Buffalo & 1 to $2 \mathrm{hrs}$ & Fair \\
\hline Pasteurized Brand A & $5 \mathrm{hrs}$ and above & Very Good \\
\hline Pasteurized Brand B & $5 \mathrm{hrs}$ and above & Very Good \\
\hline Pasteurized Brand C & 3 to $4 \mathrm{hrs}$ & Good \\
\hline Pasteurized Brand D & $\mathbf{1}$ to 2 hrs & Fair \\
\hline
\end{tabular}

Table.10 Alcohol test of milk samples

\begin{tabular}{|c|c|}
\hline Sample & Clots \\
\hline Unpasteurized Cow & Present \\
\hline Unpasteurized Buffalo & Present \\
\hline Pasteurized Brand A & Absent \\
\hline Pasteurized Brand B & Absent \\
\hline Pasteurized Brand C & Absent \\
\hline Pasteurized Brand D & Present \\
\hline
\end{tabular}

Table.11 Alcohol-Alizarin test of milk samples

\begin{tabular}{|c|c|c|c|c|}
\hline Sample & Clots & Color & HeatStability & Quality \\
\hline Unpasteurized Cow & Present & Brown & Poor & Unsatisfactory \\
\hline $\begin{array}{c}\text { Unpasteurized } \\
\text { Buffalo }\end{array}$ & Present & Pale yellow & Poor & Unsatisfactory \\
\hline Pasteurized Brand A & Absent & Pale red & Good & Satisfactory \\
\hline Pasteurized Brand B & Absent & Pale red & Good & Satisfactory \\
\hline Pasteurized Brand C & Absent & Pale red & Good & Satisfactory \\
\hline Pasteurized Brand D & Present & Brown & Poor & Unsatisfactory \\
\hline
\end{tabular}

Table.12(a) Standard bacterial plate count of milk as per U.S.Public Health Service,1995

\begin{tabular}{|c|c|}
\hline Sample & Total bacterial Standard plate count \\
\hline Unpasteurizedmilk & $\leq \mathbf{1 0 0 , 0 0 0 c f u} / \mathbf{m l}$ \\
\hline Pasteurizedmilk & $\leq \mathbf{2 0 , 0 0 0 c f u / m l}$ \\
\hline
\end{tabular}

Table.12(b) Total colony count of milk samples

\begin{tabular}{|c|c|}
\hline Sample & cfu /ml \\
\hline Unpasteurized cow & $5.15 \times 10^{\mathbf{6}}$ \\
\hline Unpasteurized buffalo & $\mathbf{6 . 0 9 \times 1 0 ^ { 6 }}$ \\
\hline Pasteurized Brand A & $2.65 \times \mathbf{1 0}^{\mathbf{6}}$ \\
\hline Pasteurized Brand B & $\mathbf{2 . 0 5} \times \mathbf{1 0}^{\mathbf{6}}$ \\
\hline Pasteurized Brand C & $\mathbf{2 . 1 5 \times 1 0 ^ { 6 }}$ \\
\hline Pasteurized Brand D & ${\mathbf{3 . 0 9} \times 10^{6}}^{6}$ \\
\hline
\end{tabular}


Table.13 Colony morphology of bacterial isolates

\begin{tabular}{|c|c|c|c|c|c|c|}
\hline \multicolumn{7}{|c|}{ Colony Characteristics } \\
\hline S.No. & Colonycolor & Size & Margin & Elevation & Texture & Opticity \\
\hline UC-1 & White & Small & Entire & Raised & Smooth & Opaque \\
\hline UC-2 & White & Small & Entire & Convex & Mucoidal & Transparent \\
\hline UC-3 & Cream & Small & Entire & Raised & Smooth & Opaque \\
\hline UB-1 & Cream & Small & Entire & Convex & Smooth & Transparent \\
\hline UB-2 & Cream & Small & Entire & Raised & Smooth & Opaque \\
\hline UB-3 & White & Large & Entire & Raised & Smooth & Opaque \\
\hline A-1 & Yellow & Small & Entire & Raised & Smooth & Opaque \\
\hline A-2 & White & Large & Entire & Convex & Mucoidal & Transparent \\
\hline B-1 & Cream & Large & Entire & Convex & Smooth & Opaque \\
\hline B-2 & Yellow & Small & Entire & Raised & Smooth & Opaque \\
\hline C-1 & Yellow & Small & Entire & Convex & Mucoidal & Transparent \\
\hline C-2 & Cream & Large & Entire & Raised & Smooth & Opaque \\
\hline C-3 & Cream & Small & Entire & Raised & Smooth & Opaque \\
\hline D-1 & Cream & Large & Entire & Convex & Mucoidal & Transparent \\
\hline D-2 & White & Small & Entire & Raised & Smooth & Opaque \\
\hline
\end{tabular}

Table.14 Growth and colony color of 15 bacterial isolates on selective and ifferential media

\begin{tabular}{|c|c|c|c|c|}
\hline S.No. & \multicolumn{2}{|c|}{ Growth on media } & Colony color & \\
\hline & EMB & MacConkey & EMB & MacConkey \\
\hline UC-1 & + & + & Green metallic sheen & Pink \\
\hline UC-2 & + & + & Green metallic sheen & Pink \\
\hline UC-3 & + & + & Green metallic sheen & Pink \\
\hline UB-1 & + & + & Green metallic sheen & Pink \\
\hline UB-2 & + & + & Green metallic sheen & Pink \\
\hline UB-3 & + & + & Green metallic sheen & Pink \\
\hline A-1 & + & + & Dark pink & Pink \\
\hline A-2 & + & + & Dark pink & Pink \\
\hline B-1 & + & + & Dark pink & Pink \\
\hline B-2 & + & + & Dark pink & Pink \\
\hline C-1 & + & + & Dark pink & Pink \\
\hline C-2 & + & + & Dark pink & Pink \\
\hline C-3 & + & + & Dark pink & Pink \\
\hline D-1 & - & - & NA & NA \\
\hline D-2 & + & + & Dark pink & Pink \\
\hline
\end{tabular}


Table.15 Morphological and biochemical characterization of bacterial isolates

\begin{tabular}{|c|c|c|c|c|c|c|c|c|c|c|c|c|c|}
\hline \multicolumn{3}{|c|}{$\begin{array}{l}\text { Morphological } \\
\text { characterization }\end{array}$} & \multirow[b]{2}{*}{ Indole } & \multirow[b]{2}{*}{ MR } & \multirow[b]{2}{*}{$\mathbf{V P}$} & \multicolumn{4}{|c|}{ Biochemical characterization } & \multirow[b]{2}{*}{ Gelatin } & \multirow[b]{2}{*}{ Oxidase } & \multirow[b]{2}{*}{ Catalase } & \multirow{2}{*}{$\begin{array}{c}\text { Identification } \\
\begin{array}{l}\text { Organism } \\
\text { identified }\end{array}\end{array}$} \\
\hline S.No. & $\begin{array}{c}\text { Gram } \\
\text { reaction }\end{array}$ & $\begin{array}{l}\text { Cellsh } \\
\text { ape }\end{array}$ & & & & Citrate & $\begin{array}{l}\text { TSI } \\
\text { test }\end{array}$ & Urease & Nitrate & & & & \\
\hline UC-1 & - & Rods & + & + & - & + & $\mathrm{A} / \mathrm{A}$ & + & + & - & - & + & $\begin{array}{c}\text { Citrobacter koseri } \\
(84.8 \%)\end{array}$ \\
\hline $\mathrm{UC}-2$ & - & Rods & + & + & - & - & $\mathrm{A} / \mathrm{A}$ & + & + & - & - & + & E.coli $(81 \%)$ \\
\hline $\mathrm{UC-3}$ & - & Rods & + & + & + & + & $\mathrm{A} / \mathrm{A}$ & + & + & - & - & + & Klebsiella (82\%) \\
\hline UB-1 & - & Rods & + & - & - & - & $\mathrm{A} / \mathrm{A}$ & - & + & - & - & + & E.coli $(81.2 \%)$ \\
\hline UB-2 & - & Rods & + & - & + & - & $\mathrm{A} / \mathrm{A}$ & - & + & - & - & + & E.coli $(81.2 \%)$ \\
\hline UB-3 & - & Rods & + & - & + & + & $\mathrm{A} / \mathrm{A}$ & - & + & - & - & + & $\begin{array}{c}\text { Enterobacter } \\
\text { aerogenes } \\
(81.2 \%)\end{array}$ \\
\hline A-1 & - & Rods & - & + & + & + & $\mathrm{K} / \mathrm{K}$ & + & + & + & - & + & $\begin{array}{c}\text { Pseudomonas } \\
(71 \%)\end{array}$ \\
\hline A-2 & - & Rods & + & + & + & + & $\mathrm{A} / \mathrm{A}$ & + & + & + & - & + & Proteus (80.4\%) \\
\hline B-1 & - & Rods & + & + & + & + & $\mathrm{K} / \mathrm{A}$ & + & + & - & + & + & Klebsiella (82.1\%) \\
\hline B-2 & - & Rods & + & + & - & + & $\mathrm{K} / \mathrm{A}$ & + & + & - & + & + & $\begin{array}{c}\text { Citrobacter } \\
(80.1 \%)\end{array}$ \\
\hline C-1 & - & Rods & - & - & + & + & $\mathrm{K} / \mathrm{A}$ & - & + & - & + & + & $\begin{array}{c}\text { Enterobacteraerog } \\
\text { enes }(88 \%)\end{array}$ \\
\hline C-2 & - & Rods & + & + & + & + & $\mathrm{A} / \mathrm{A}$ & - & + & - & + & + & Notidentified \\
\hline C-3 & - & Rods & - & + & + & + & $\mathrm{A} / \mathrm{A}$ & - & + & - & + & + & $\begin{array}{c}\text { Enterobacter } \\
(88.1 \%)\end{array}$ \\
\hline D-1 & + & Rods & - & - & + & + & $\mathrm{K} / \mathrm{A}$ & + & + & + & - & + & Notidentified \\
\hline D-2 & - & Rods & + & - & + & + & $\mathbf{K} / \mathbf{A}$ & + & + & + & - & + & $\begin{array}{c}\text { Klebsiella } \\
(89.3 \%)\end{array}$ \\
\hline
\end{tabular}


The study showed that out of 417 raw milk samples, 12 samples coagulated by $69 \%$ alcohol, 32 samples by $70 \%$ alcohol, 107 samples by $74 \%$ alcohol, 125 samples by $78 \%$ and 141 samples by $82 \%$ alcohol. Kentaro demonstrated that more number of samples coagulated with stronger alcohol.

\section{The Alcohol-Alizarin Test}

Results obtained from the Alcohol-Alizarin test and their interpretation has been shown in Table 11.

Presence of small lumps or heavy coagulation is an indication of sour or milk. The above results indicate that Unpasteurized milk samples have poor heat stability which also refers to their unsatisfactory quality. The reason behind this could be high developed acidity, or presence of calcium and magnesium compounds in greater than normal amounts (Lusato et al., 2006).

\section{Microbial analysis of milk sample}

Milk samples collected from local vendors (unpasteurized cow and buffalo) and shops (branded samples: Brand A, Brand B, Brand C and Brand D) were tested by spread-plate technique on Nutreint (NA) medium to find the $\mathrm{cfu} / \mathrm{ml}$.

The colony count was seen highest in unpasteurized milk samples which could most probably happen due to their sale in open conditions with less sanitary measures and without any sealed packaging which can thereby introduce contamination. Pasteurized branded milk samples also showed a high bacteria count as shown in Table 12 (b). Umofia et al., (2015) conducted a similar study in which 200 packaged branded milk samples were collected from 5 sources. The study revealed that the bacterial load obtained in branded milk samples ranged from 1.10-
$19.20 \times 10^{6} \mathrm{cfu} / \mathrm{ml}$. Based on these findings they concluded that there was a lack of strict hygienic measures during production, processing and distribution of the collected milk samples. The study further revealed that the key to prevent contamination of milk is to prevent post-pasteurization contamination through well-designed quality assurance. In another similar study conducted by Hasan et al., (2015) a total of 32 milk samples (12 from raw milk and 20 from pasteurized milk) were collected from 8 sources. Total Viable Count (TVC) range of rawmilk samples were $1.3 \times 10^{6}$ to $7.4 \times 10^{5} \mathrm{cfu} / \mathrm{ml}$. Whereas, the range of TVC for brands of pasteurized milk were from $1.8 \times 10^{4}$ to $9.8 \times 10^{4}$. They concluded that high counts of bacteria were found in both raw and pasteurized milk. The reason for high bacterial count in pasteurized milk may include defective pasteurization machinery, survival of more after pasteurization, and postpasteurization contamination and poor hygiene.

\section{Isolation of Bacteria from milk sample}

Bacterial species were isolated from milk samples and named UC-1,UC-2,UC-3 for unpasteurized cow sample; UB-1, UB-2, UB-3 for unpasteurized buffalo sample; A-1, A-2 for Brand A sample; B-1,B-2 for Brand B sample; C-1,C-2,C-3 for Brand C sample; and D-1,D-2 for Brand $\mathrm{D}$ sample. Thus, a total of 15 bacterial isolates were obtained.

\section{Colony and Morphological characterization of bacterial isolates}

The colony and morphological characterization of all bacterial isolates are shown in Table 13 and Table 15.

\section{Screening of bacterial isolates}

The bacterial isolates were able to grow on EMB agar medium and MacConkey agar 
medium. On EMB medium UC1, UC2, UC3, $\mathrm{UB} 1, \mathrm{UB} 2$ and UB3 isolates produced a green metallic sheen appearing as E.coli. and A1, A2, B1, B2, C1, C2, C3, D2 produced dark purple colonies indicating lactose fermenting bacteria. D1 showed no growth on EMB. On Mac Conkey medium all the isolates appeared as pink colored, lactose-fermenting colonies except for D1 which showed no growth as shown in Table 14.

\section{Biochemical characterization of bacterial isolates}

The different bacterial isolates were characterized based on various biochemical tests as shown in Table 15. Umofia et al., (2014) conducted a similar study in which a total of 153 bacterial isolates were identified from 200 packaged branded milk samples out of which some of the identified species and their prevalence rates were E. coli $(13.1 \%)$, Proteus species (2.6\%),Salmonella species (0.65\%), Providencia species (3.26\%), Enterobacter species (36.6\%), Citrobacter species (0.65\%), Klebsiella species (1.31\%), Yersinia species (0.65\%), Pseudomonas species $(37.9 \%)$ and S. aureus $(3.28 \%)$. They concluded that most the organisms identified belonged to Enterobacteriaceae family, thus indicating probable faecal contamination of the milk as a result of poor hygiene during production processes. The study revealed that packaged milk is a potential hazard of pathogenic food borne bacteria that may have public health implications.

\section{References}

Beauchemin, K. A., Yang, W. Z., \& Penner, G. (2006). Ruminal acidosis in dairy cows: Balancing effective fiber with starch availability. In Proc. of the 41st Annual Pacific Northwest Animal Nutrition Conference, Vancouver, BC (pp. 5-17).
Chandraprakash D. Khedkar, Shrikant D Kalyankar(2016). Buffalo milk, In: caballero, B., Finglas, p., and Toldra, F. (eds). The Encyclopedia of Food and Health 1: 522-528, Oxford Academic Press.

Gedam, K., Prasad, R., Vijay, V. K., \& Chanda, G. C. (2007). The study on UHT processing of milk: A versatile option for rural sector. World J. Dairy Food Sci, 2(2), 49-53.

Ghada Z. A. S. (2005). Comparison of chemical and mineral content of milk from cow, buffalo, human, camel, and goat in Egypt. The Egyptian Journal of Hospital Medicine 21:116-130.

Guetouache M., Bettache G. and Medjekal S. (2014). Compositional and nutritional value of raw milk. Biological Sciences and

Pharmaceutical

Research.2(10):115-112

Helmenstine, Anne Marie, Ph.D. (2020). What Is the Acidity or $\mathrm{pH}$ of Milk? Retrieved from https://www.thoughtco.com/what-isthe-ph-of-milk-603652

Jenness, R., Wong, N. P., Marth, E. H., \& Keeney, M. (1988). Fundamentals of dairy chemistry. Springer Science \& Business Media.

Juárez-Barrientos, J. M., Díaz-Rivera, P., Rodríguez-Miranda, J., MartínezSánchez, C. E., Hernández-Santos, B., Ramírez-Rivera, E.,... \& Herman-Lara, E. (2016). Characterization of milk and quality classification by Cluster analysis in dual purpose systems. Revista mexicana de ciencias pecuarias, 7(4), 525-537.

Konte M (1999). Le lait et les produits laitiers. Développement de systèmes de productions intensives en Afrique de l'ouest. Université de Nouakchott (R.I.M) Faculté des Sciences et Technologies des aliments, B. P. 5026. ISRA/ URV - LNERV/FEVRIER : 2- 
25.

Lusato, R. K. (2006). Hygienic Milk Handling, Processing and Marketing. Tanzania Dairy Board Trainers Guide.

Matofari, J. W., Shalo, P. L., Younan, M., Adongo, J. N., Qabale, A., \& Misiko, B. N. (2013). Analysis of microbial quality and safety of camel (Camelus dromedarius) milk chain and implications in Kenya.

Md. Hasan., Md. Aminul I., Md. Showkat M., and Shamim A. (2015). Microbial analysis of raw and pasteurized milk from selected areas of Dinajpur, Bangladesh. Asian Journal of Medical and Biological Research. 1(2):292296.

Mitamura, K. (1937). Studies on the alcohol coagulation of fresh cow milk. Journal of the Faculty of Agriculture, Hokkaido Imperial University, 41(2), 97-362.

Oliver, S. P., Kathryn, J. B., Steven, C. M., Shelton, E. M., (2009). Food Safety hazardous associated with consumption of milk. Food borne pathogens and diseases. 6(7):793-806.

Rajagopal, B., Werner, G. Hotchkiss J. H. (2005). Low pressure carbon dioxide storage of raw milk: microbiological effects. Journal of Dairy Science. 88:3130-3138.

Saiqa B., Muhammad S. A., Shahzad A. K., Habib A. R., Muhammad A. Q., Zulfiqar H. K. (2013). An evaluation of milk quality in and around Rawalakot Azad Kashmir. African journal of Food science, 7(11): 421427

Soliman, G. Z. (2005). Comparison of chemical and mineral content of milk from human, cow, buffalo, camel and goat in Egypt. The Egyptian Journal of Hospital Medicine, 21(1), 116-130.

Sudhasarvanan, R. And Binukumari, S. (2015). Microbial quality of raw and pasteurized milk samples collected from different regions of Madurai District, (T.N.) India. IOSR Journal of Environmental Science, Toxicology and Food Technology. 9(1):2319-2399

Umofia, I. D., Igwe, J. C., Adeshina, G. O., Ehinmidu, J. O., Ojiego B. O., Kachallah M., Enose O. Dauda, Oladipo H. O., Adeboye S.(2014). Bacteriological Examination of Packaged milk marketed in Zaria, Nigeria. International Journal of Current Research.6(8):7836-7841.

\section{How to cite this article:}

Prerna Sinha, Sumedha Srivastava, Sefali Gupta and Verma, O. P. 2021. Microbial Analysis and Quality Assurance of Unpasteurized Raw and Pasteurized Branded Milk. Int.J.Curr.Microbiol.App.Sci. 10(08): 510-522. doi: https://doi.org/10.20546/ijcmas.2021.1008.061 